\title{
Peter Macnair, F.G.S.
}

The late Mr Peter Macnair, who died very suddenly on 29th March 1929, at the age of sixty-one, was Curator of the Zoological and Geological Collections in the Kelvingrove Museum, Glasgow. He had also held the Lectureship in Geology at the Royal Technical College, Glasgow, for some years, and up to a short time before his death he occupied the Chair of Zoology at the Andersonian Medical College, Glasgow. A self-taught man in geology and zoology, he acquitted himself with much distinction in both sciences, and was for many years a prominent figure in the scientific circles of the West of Scotland. Owing to the nature of his scientific equipment he excelled in palæontology, and his museum work in that and in other departments of geology was brilliant in idea and in execution. His research, however, embraced a far wider field. He was interested in the complicated tectonic structures of the Grampians and in the origin of the Old Red Sandstone. His largest work, The Geology and Scenery of the Grampians (Glasgow: MacLehose, 1908, 2 vols.), was mainly concerned with these subjects. He applied the view of Alpine fan (facher) structure to the Grampians, and was probably the last remaining advocate of the marine origin of the Old Red Sandstone. His palæontological work led him to study the stratigraphical relations of the Carboniferous Limestone Series in the Midland Valley of Scotland, and many of his later memoirs were devoted to this subject. He was at one time the President of the Geological Society of Glasgow. He became a member of the Royal Society of Edinburgh in 1907, and published a paper on "The Hurlet Sequence . . ." in the Proceedings (vol. xxxvii, 1917, pp. 173-209).

G. W. T. 